\title{
PENGARUH VARIABEL EKONOMI MAKRO TERHADAP KEMISKINAN DI KOTA MAKASSAR PROVINSI SULAWESI SELATAN
}

\author{
Siti Walida Mustamin \\ Dosen Prodi Hukum Ekonomi Syariah FAl Unismuh Makassar \\ Email ; walida.mustamin@yahoo.co.id
}

\begin{abstract}
Abstrak
Kemiskinan merupakan salah satu masalah yang sangat penting untuk diberikan solusi dalam ekonomi, sehingga harus dihilangkan atau paling tidak dikurangi. Penelitian ini bertujuan mengetahui pengaruh belanja pemerintah, inflasi, dan investasi terhadap kemiskinan (baik secara langsung maupun tidak langsung) melalui pertumbuhan ekonomi, dan pengaruh pertumbuhan ekonomi terhadap terhadap kemiskinan (baik secara langsung dan tidak langsung) melalui tingkat pengangguran terbuka dan pendapatan perkapita di Kota Makassar, Provinsi Sulawesi Selatan, mulai 1999-2013. Penelitian ini menggunakan data sekunder. Model analisis yang digunakan, yaitu analisis $P$ ath dengan alasan untuk menjelaskan akibat langsung dan tidak langsung seperangkat variabel sebagai variabel independen terhadap variabel lainnya yang merupakan variabel dependen yang terdapat persamaan struktural. Hasil penelitian ini menunjukan bahwa: (1) Belanja pemerintah secara langsung berpengaruh negatif terhadap kemiskinan, sedangkan pengaruh belanja pemerintah secara tidak langsung berpengaruh positif terhadap kemiskinan melalui pertumbuhan ekonomi; (2) Inflasi secara langsung berpengaruh negatif terhadap kemiskinan, sedangkan pengaruh inflasi secara tidak langsung berpengaruh positif terhadap kemiskinan melalui pertumbuhan ekonomi; (3) Investasi secara langsung tidak berpengaruh terhadap kemiskinan, sedangkan pengaruh investasi secara tidak langsung tidak berpengaruh terhadap kemiskinan melalui pertumbuhan ekonomi; dan (4) Pertumbuhan ekonomi secara langsung tidak berpengaruh terhadap kemiskinan, sedangkan pengaruh pertumbuhan ekonomi secara tidak langsung berpengaruh negatif terhadap kemiskinan melalui pengangguran dan pengaruh pertumbuhan ekonomi secara tidak langsung tidak berpengaruh terhadap kemiskinan melalui pendapatan perkapita
\end{abstract}

Kata Kunci : Belanja Pemerintah, Inflasi, Investasi, Pertumbuhan Ekonomi, Kemiskinan

Abstract

Poverty is one important issue that requires economics solution is order to be eliminated or at least reduced. This research aimed investigate the effects of the government spending, inflation, and investment on the poverty, both direct and indirect thorough the economic growth, and the effects of the economic growth on the poverty, both direct and indirect through the open unemployment and the income per capita in Makassar City, South Sulawesi Province from 1999 through 2013. The research used secondary data. the direct and the indirect wastects of ath analysis, since the research aimed explain both another variable as the dependent variable found in thes as the independent variabies on indicate that (1) the government variable found in the structural equation. These results effect of government spending indirect postiv negative effect on poverty, while the growth; (2) Inflation directly negativect positive effect on poverty through economic indirect positive effect on poverty thro effect on poverty, whereas the effect of inflation effect on poverty, whereas the effect of indirect growth; (3) direct investment has no through economic growth; and (4) the economirect investment has no effect on poverty poverty, whrereas the effect of economic growth directly did not have effect on unemployment and poverty through economic growth indirectly negatively affect through income per kapita.

Keywords : Government Spending, Inflation, Investement, Economic Growth, Poverty 


\section{A. PENDAHULUAN}

Salah satu tujuan pembangunan nasional adalah meningkatkan kinerja perekonomian agar mampu menciptakan lapangan kerja dan menata kehidupan yang layak bagi seluruh rakyat yang pada gilirannya akan mewujudkan kesejahteraan penduduk di suatu negara. Untuk Negara Indonesia salah satu sasaran pembangunan nasional adalah untuk menurunkan tingkat kemiskinan.

Masalah kemiskinan selalu memperoleh perhatian utama di Indonesia. Hal ini terjadi karena adanya kesadaran pemerintah bahwa kegagalan mengatasi persoalan kemiskinan akan dapat menyebabkan munculnya berbagai persoalan sosial, ekonomi, dan politik di tengah- tengah masyarakat. Oleh sebab itu, kemiskinan menjadi masalah yang penting di Indonesia dan menjadi fokus perhatian bagi pemerintah Indonesia dan terkhusus untuk wilayah Kota Makassar di Provinsi Sulawesi Selatan.

Friedman dalam Abilawa (2010), mendefinisikan kemiskinan sebagai ketidaksamaan kesempatan untuk mengakumulasikan basis kekuatan sosial.

Menurut Todaro (2000), meskipun laju pertumbuhan ekonomi tidak secara otomatis dapat memberi jawaban atas berbagai macam persoalan kesejahteraan, namun hal tersebut tetap merupakan unsur penting setiap program pembangunan realistis yang sengaja dirancang untuk mengentaskan kemiskinan.

Berdasarkan penjelasan tersebut maka hubungan antara beberapa variabel makro ekonomi dengan kemiskinan, ada yang memberikan dampak positif dan negatif. Seperti halnya apabila masalah belanja pemerintah dihubungkan dengan kemiskinan dimana saat belanja pemerintah meningkat, maka kemiskinan yang ada pada suatu daerah akan menurun. Namun yang menjadi masalah di Kota Makassar dengan alokasi belanja pemerintah yang naik setiap tahun, apakah dapat menurunkan angka kemiskinan yang ada di Kota Makassar . Berdasarkan fenomena ini maka tujuan penelitian diarahkan untuk mengetahui pengaruh belanja pemerintah, inflasi dan investasi terhadap kemiskinan baik secara langsung maupun tidak langsung melalui pertumbuhan ekonomi dan pengaruh pertumbuhan ekonomi terhadap kemiskinan baik secara langsung maupun tidak langsung melaui tingkat pengangguran terbuka dan pendapatan per kapita di Kota Makassar.

\section{B. METODE PENELITIAN}

\section{Lokasi dan Rancangan Penilitian}

Penelitian ini dilaksanakan di Kota Makassar Provinsi Sulawesi Selatan. Sedangkan Penelitian ini adalah penelitian yang menggunakan pendekatan kuantitatif dengan menggunakan variabel dependen yaitu 
kemiskinan di Kota Makassar Provinsi Sulawesi Selatan dan variabel independen yaitu belanja pemerintah, inflasi dan investasi. Data yang diambil dalam kurun waktu 15 tahun yaitu dari tahun 1999-2013.

\section{Metode pengumpulan Data}

Penelitian ini menggunakan metode pengumpulan data dengan cara dokumentasi yaitu cara pengumpulan data dengan jalan mengumpulkan data melalui keterangan secara tertulis yang merupakan dokumen- dokumen yang ada hubungannya dengan data yang dibutuhkan dalam penelitian dan dengan riset kepustakaan yang merupakan teknik analisis untuk mendapatkan informasi melalui catatan, literatur dan lain- lain yang masih relevan.

\section{Motode Analisis Data}

Metode Analisis data yang digunakan dalam penelitian ini adalah Statistik deskriptif dan statistik inferensial. Adapun model yang digunakan yaitu Adapun model analisis yang akan digunakan adalah model analisis jalur / Path Analysis untuk mejelaskan akibat langsung dan tidak langsung seperangkat variabel, sebagai variabel penyebab, terhadap variabel lainnya yang merupakan variabel akibat yang terdapat dalam persamaan struktural. Model analisis yang dibangun dalam penelitian ini adalah:

$$
\begin{gathered}
Y_{1}=\alpha_{0}+\alpha_{1} L_{n} X_{1}+\alpha_{2} X_{2}+\alpha_{3} L_{n} X_{3}+\alpha_{4} L_{n} Y_{2}+\alpha_{5} L_{n} Y \\
{ }_{3}+\alpha_{6} Y_{4}+\mu_{1} \ldots \ldots \ldots \ldots \ldots \ldots \ldots \ldots \ldots \ldots \ldots \ldots \ldots \ldots \\
Y_{2}=Y_{0}+Y_{1} L_{n} X_{1}+Y_{2} X_{2}+Y_{3} L_{n} X_{3}+Y_{4} Y_{4}+\mu_{2} \ldots \\
Y_{3}=\beta_{0}+\beta_{1} L_{n} X_{1}+\beta_{2} X_{2}+\beta_{3} L_{n} X_{3}+\beta_{4} Y_{4}+\mu_{3 . .} \\
Y_{4}=\xi_{0}+\xi_{1} L_{n} X_{1}+\xi_{2} X_{2}+\xi_{3} L_{n} X_{3}+\mu_{4} \ldots \ldots \ldots \text { (1.4) }
\end{gathered}
$$

Dimana :

$\mathrm{X}_{1}=$ Belanja Pemerintah $(\mathrm{Rp})$

$X_{2}=$ Inflasi $(\%)$

$\mathrm{X}_{3}=$ Investasi $(\mathrm{Rp})$

$\mu=$ Error

$Y_{1}=$ Kemiskinan (\%)

$Y_{2}=$ Pengangguran (Jiwa)

$Y_{3}=$ Pendapatan Perkapita $(R p)$

$\mathrm{Y}_{4}=$ Pertumbuhan Ekonomi (\%)

\section{HASIL PENELITIAN}

Pada Tabel 1 dan Tabel 2 menunjukkan pengaruh masing-masing variabel independen terhadap kemiskinan. Hasil analisis menunjukan hubungan yang terjadi antara belanja pemerintah, inflasi, investasi, tingkat pengangguran terbuka, pendapatan per kapita dan pertumbuhan ekonomi terhadap tingkat kemiskinan dalam periode penelitian tahun 1999 sampai tahun 2013 ditunjukan pada tabel berikut:

\section{Pengaruh Belanja Pemerintah}

Terhadap Pertumbuhan Ekonomi

Hasil penelitian menunjukkan bahwa secara statistik variabel belanja pemerintah mempunyai efek langsung terhadap pertumbuhan ekonomi sebesar 
3,038. Hal ini berarti setiap kenaikan belanja pemerintah sebesar 1 milyar rupiah diikuti peningkatan pertumbuhan ekonomi sebesar 3,038 persen dengan tingkat signifikansi 1 persen.

Pengaruh Investasi Terhadap Pertumbuhan Ekonomi

Hasil penelitian menunjukkan bahwa secara statistik variabel investasi mempunyai efek langsung terhadap pertumbuhan ekonomi sebesar $-0,661$. $\mathrm{Hal}$ ini berarti setiap kenaikan investasi sebesar 1 milyar rupiah diikuti penurunan pertumbuhan ekonomi sebesar 0,661 persen dengan tingkat signifikansi 1 persen.

\section{Pengaruh Belanja Pemerintah}

\section{Terhadap Kemiskinan}

Hasil penelitian menunjukkan bahwa secara statistik variabel belanja pemerintah mempunyai efek langsung terhadap kemiskinan sebesar -2,273. Hal ini berarti setiap kenaikan belanja pemerintah sebesar 1 milyar rupiah diikuti penurunan kemiskinan sebesar 2,273 persen dengan tingkat signifikansi 1 persen.

\section{Pengaruh Investasi Terhadap}

\section{Pendapatan Per Kapita}

Hasil penelitian menunjukkan bahwa secara statistik variabel investasi mempunyai efek langsung terhadap pendapatan per kapita sebesar 0,075. $\mathrm{Hal}$ ini berarti setiap kenaikan investasi sebesar 1 milyar rupiah diikuti peningkatan pendapatan per kapita sebesar 0,075 juta rupiah dengan tingkat signifikansi 1 persen.

\section{Pengaruh Inflasi Terhadap Kemiskinan}

Hasil penelitian menunjukkan bahwa secara statistik variabel inflasi mempunyai efek langsung terhadap kemiskinan sebesar $-0,088$. Hal ini berarti setiap kenaikan inflasi sebesar 1 persen diikuti penurunan kemiskinan sebesar 0,088 persen dengan tingkat signifikansi 5 persen.

Pengaruh Inflasi Terhadap

\section{Pertumbuhan Ekonomi}

Hasil penelitian menunjukkan bahwa secara statistik variabel inflasi mempunyai efek langsung terhadap pertumbuhan ekonomi sebesar 0,085 . Hal ini berarti setiap kenaikan inflasi sebesar 1 persen diikuti peningkatan pertumbuhan ekonomi sebesar 0,085 persen dengan tingkat signifikansi 5 persen.

Pengaruh Pengangguran Terhadap Kemiskinan

Hasil penelitian menunjukkan bahwa secara statistik variabel pengangguran mempunyai efek langsung terhadap kemiskinan sebesar 0,402 . Hal ini berarti setiap kenaikan pengangguran sebesar 1 ribu jiwa diikuti peningkatan kemiskinan sebesar 0,402 persen dengan tingkat signifikansi 5 persen.

\section{Pengaruh Belanja PemerintahTerhadap}

Pendapatan Per Kapita

Hasil penelitian menunjukkan bahwa secara statistik variabel belanja pemerintah mempunyai efek langsung 
terhadap pendapatan per kapita sebesar 0,183 . Hal ini berarti setiap kenaikan belanja pemerintah sebesar 1 milyar rupiah diikuti peningkatan pendapatan per kapita sebesar 0,183 juta rupiah dengan tingkat signifikansi 10 persen.

\section{Pengaruh \\ Inflasi \\ Terhadap \\ Pengangguran \\ Hasil penelitian menunjukkan} bahwa secara statistik variabel inflasi mempunyai efek langsung terhadap pengangguran sebesar 0,071 . Hal ini berarti setiap kenaikan inflasi sebesar 1 persen diikuti peningkatan pengangguran sebesar 0,071 jiwa dengan tingkat signifikansi 10 persen.

\section{Pengaruh Investasi Terhadap} Pengangguran

Hasil penelitian menunjukkan bahwa secara statistik variabel investasi mempunyai efek langsung terhadap pengangguran sebesar $-0,318$. Hal ini berarti setiap kenaikan investasi sebesar 1 milyar rupiah diikuti penurunan pengangguran sebesar 0,318 jiwa dengan tingkat signifikansi 10 persen.

\section{Pengaruh Belanja Pemerintah}

Terhadap Pengangguran

Hasil penelitian menunjukkan bahwa secara statistik variabel belanja pemerintah mempunyai efek langsung terhadap pengangguran sebesar 0,936. Hal ini berarti setiap kenaikan belanja pemerintah sebesar 1 milyar rupiah diikuti peningkatan pengangguran sebesar 0,936 ribu jiwa dengan tingkat signifikansi
0,226 . Hal ini berarti variabel belanja pemerintah tidak signifikan dan negatif mempengaruhi kemiskinan.

\section{Pengaruh Pertumbuhan Ekonomi Terhadap Pengangguran}

Hasil penelitian menunjukkan bahwa secara statistik variabel pertumbuhan ekonomi mempunyai efek langsung terhadap pengangguran sebesar -0,355. Hal ini berarti setiap kenaikan pertumbuhan ekonomi sebesar 1 persen diikuti penurunan pengangguran sebesar 0,355 ribu jiwa dengan tingkat signifikansi 0,151 . Hal ini berarti variabel pertumbuhan ekonomi tidak signifikan dan negatif mempengaruhi pengangguran.

\section{Pengaruh Pertumbuhan Ekonomi}

\section{Terhadap Pendapatan Per Kapita}

Hasil penelitian menunjukkan bahwa secara statistik variabei pertumbuhan ekonomi mempunyai efek langsung terhadap pendapatan per kapita sebesar -0,009. Hal ini berarti setiap kenaikan pertumbuhan ekonomi sebesar 1 persen diikuti penurunan pendapatan perkapita sebesar 0,009 juta rupiah dengan tingkat signifikansi 0,765 . Hal ini berarti variabel pertumbuhan ekonomi tidak signifikan dan negatif mempengaruhi pendapatan per kapita.

\section{Pengaruh Investasi Terhadap Kemiskinan \\ Hasil penelitian menunjukkan} bahwa secara statistik variabel investasi 
mempunyai efek langsung terhadap kemiskinan sebesar $-0,223$. Hal ini berarti setiap kenaikan investasi sebesar 1 milyar rupiah diikuti penurunan kemiskinan sebesar 0,223 persen dengan tingkat signifikansi 0,264 . Hal ini berarti variabel investasi tidak signifikan dan negatif mempengaruhi kemiskinan.

\section{Pengaruh Pertumbuhan Ekonomi} Terhadap Kemiskinan

Hasil penelitian menunjukkan bahwa secara statistik variabel pertumbuhan ekonomi mempunyai efek langsung terhadap kemiskinan sebesar 0,306 . Hal ini berarti setiap kenaikan pertumbuhan ekonomi sebesar 1 persen diikuti peningkatan kemiskinan sebesar 0,306 persen dengan tingkat signifikansi 0,131. Hal ini berarti variabel pertumbuhan ekonomi tidak signifikan dan positif mempengaruhi kemiskinan.

\section{Pengaruh Pendapatan Per Kapita Terhadap Kemiskinan}

Hasil penelitian menunjukkan bahwa secara statistik variabel pendapatan per kapita mempunyai efek langsung terhadap kemiskinan sebesar 0,996 . Hal ini berarti setiap kenaikan pendapatan per kapita sebesar 1 juta rupiah diikuti peningkatan kemiskinan sebesar 0,996 persen dengan tingkat signifikansi 0,531 . Hal ini berarti variabel pendapatan per kapita tidak signifikan dan positif mempengaruhi kemiskinan.

\section{Pembahasan Hasil Penelitian}

Hasil penelitian ini menunjukan belanja pemerintah berpengaruh negatif terhadap kemiskinan. Hasil penelitian ini yang telah dilakukan sejalan dengan hasil penelitian yang telah dilakukan oleh Paseki dkk (2014), yang mengatakan bahwa variabel belanja langsung secara langsung berpengaruh terhadap penurunan tingkat kemiskinan di Kota Manado. Hasil perbedaan penelitian yang dilakukan oleh Hasil Sari (2013), yang mengatakan bahwa pengeluaran pemerintah di bidang kesehatan tidak berpengaruh terhadap tingkat kemiskinan karena adanya pemberian bantuan yang tidak tepat sasaran. Adanya pengaruh yang negatif antara belanja pemerintah terhadap kemiskinan disebabkan karena adanya peningkatan belanja pemerintah dari tahun ke tahun yang dilakukan oleh pemerintah di Kota Makassar memberikan dampak yang positif terhadap penurunan tingkat kemiskinan yang ada di Kota Makassar.

Berdasarkan hasil pengolahan data menunjukan bahwa pengaruh belanja pemerintah secara tidak langsung berpengaruh positif terhadap kemiskinan melalui pertumbuhan ekonomi. $\mathrm{Hal}$ ini menunjukkan belanja pemerintah belum mampu mendorong pertumbuhan ekonomi dan peningkatan pendapatan perkapita masyarakat terkhusus di Kota Makassar. Namun apabila dilakukan dengan cara adanya peningkatan 
pendapatan per kapita yang ada pada daerah tersebut, maka secara langung dapat menurunkan tingkat kemiskinan.

Berdasarkan hasil pengolahan data menunjukan inflasi berpengaruh negatif terhadap tingkat kemiskinan di Kota Makassar. Hasıl perbedaan penelitian yang dilakukan oleh Yudha (2013), yang mengatakan bahwa berdasarkan hasil analisis variabel inflasi berpengaruh positif terhadap kemiskinan di Indonesia tahun 2009 sampai 2011. Adanya hubungan yang negatif antara inflasi terhadap kemiskinan, memberikan implikasi bahwa walaupun data menunjukkan tingkat inflasi yang ada di Kota Makassar mengalami fluktuatif, maka tidak berimplikasi terhadap penurunan tingkat kemiskinan di Kota Makassar. Di samping itu adanya hasil yang negatif antara inflasi terhadap kemiskinan, karena adanya kondisi dan situasi di mana daya beli masyarakat dalam suatu daerah bersifat heterogen atau tidak sama, sehingga selanjutnya akan terjadi realokasi barang-barang yang tersedia dari golongan masyarakat yang memilik daya beli yang relatif rendah kepada golongan masyarakat yang memiliki daya beli yang lebih besar.

Berdasarkan hasil pengolahan data menunjukan bahwa inflasi secara tidak langsung berpengaruh positif terhadap kemiskinan melalui pertumbuhan ekonomi. Adanya pengaruh yang positif antara inflasi terhadap kemiskinan disebabkan karena adanya dampak inflasi yang timbulkan terhadap pendapatan yaitu Inflasi dapat mengubah pendapatan masyarakat. Pada beberapa kondisi inflasi dapat menurunkan perkembangan ekonomi. inflasi dapat membuat para para pengusaha untuk mengurangi jumlah produksinya. Dengan demikian, kesempatan kerja baru akan berkurang sehingga dapat menyebabkan pendapatan masyarakat menurun. Dan yang lebih parah lagi, dampak inflasi dapat lebih dirasakan bagi masyarakat yang berpenghasilan tetap, dimana inflasi akan menyebabkan mereka rugi karena penghasilan yang tetap itu jika ditukarkan dengan barang dan jasa akan semakin sedikit.

Berdasarkan hasil pengolahan data menunjukan bahwa investasi tidak berpengaruh terhadap kemiskinan di Kota Makassar. Hasil penelitian ini tidak sejalan teori yang diungkapkan oleh Sukirno (2000), yang mengatakan bahwa kegiatan investasi yang dilakukan oleh masyarakat secara terus menerus akan meningkatkan kegiatan ekonomi dan kesempatan kerja, meningkatkan pendapatan nasional dan meningkatkan taraf kemakmuran masyarakat. Hasil perbedaan penelitian yang dilakukan oleh Aritonang (2012), yang mengatakan bahwa bahwa adanya hubungan yang negatif dan signifikan antara investasi terhadap tingkat kemiskinan dilakukan di Indonesia untuk periode 1981 - 2011. 
Adanya hasil yang tidak berpengaruh antara investasi dengan kemiskinan disebabkan pula oleh diduga bahwa kebanyakan investasi yang ada di Kota Makassar hanya dilakukan oleh kaum menengah ke atas, dan itu hanya berdampak pada kehidupan mereka masing- masing, dan tidak memberikan pengaruh terhadap kehidupan penduduk miskin. Di samping itu, karena adanya investasi yang lebih terkonsentrasi pada pembangunan sektor-sektor yang kurang menyerap tenaga kerja, seperti sub sektor kehutanan (logging), industri kimia, dan belanja sekretariat DPRD.

Berdasarkan hasil pengolahan data menunjukan bahwa investasi secara tidak langsung tidak berpengaruh terhadap kemiskinan melalui pertumbuhan ekonomi. Lemah nya hubungan antara investasi terhadap kemiskinan menunjukkan adanya dampak bahwa tingginya investasi yang lebih diarahkan untuk meningkatkan pertumbuhan ekonomi, dibandingkan untuk menurunkan kemiskinan dan karena adanya iklim investasi yang tidak kondusif menyebabkan angka kemiskinan di Kota Makassar mengalami peningkatan.

Berdasarkan hasil pengolahan data menunjukan bahwa pertumbuhan ekonomi tidak berpengaruh terhadap kemiskinan di Kota Makassar. Perbedaan hasil penelitian yang dilakukan oleh Prastyo (2010), yang mengtakan bahwa koefisien dari pertumbuhan ekonomi signifikan secara statistik terhadap kemiskinan. Adanya hasil yang tidak berpengaruh antara pertumbuhan ekonomi terhadap kemiskinan, karena pertumbuhan ekonomi belum efektif dalam mengurangi kemiskinan, di mana pertumbuhan ekonomi tersebut belum merata di setiap golongan pendapatan, termasuk kelompok penduduk miskin.

Berdasarkan hasil pengolahan data menunjukan bahwa pengaruh pertumbuhan ekonomi secara tidak langsung berpengaruh negatif terhadap kemiskinan melalui pengangguran. Adanya hasil yang negatif antara pertumbuhan ekonomi dengan kemiskinan disebabkan karena pertumbuhan ekonomi ternyata efektif dalam mengurangi kemiskinan, dengan cara mengurangi pengangguran yang ada, seperti dengan menyediakannya lapangan pekerjaan bagi kalangan yang tergolong dalam kategori menganggur.

Berdasarkan hasil pengolahan data menunjukan bahwa pengaruh pertumbuhan ekonomi secara tidak langsung tidak berpengaruh terhadap kemiskinan melalul pendapatan per kapita. Adanya hasil yang tidak berpengaruh antara pertumbuhan ekonoml dengan kemiskinan melalul pendapatan per kapita disebabkan karena adanya data menunjukkan bahwa peningkatan yang terjadl pada 
pertumbuhan ekonomi setiap tahunnya ternyata tidak memberikan dampak positif bagi masyarakta miskin, karena peningkatan pertumbuhan ekonomi belum merata di setiap golongan pendapatan sehingga menyebabkan pendapatan per kapita yang terdapat dı Kota Makassar tetap mengalami fluktuasi.

\section{KESIMPULAN}

Hasil penelitian menunjukkan bahwa belanja pemerintah secara langsung berpengaruh negatif terhadap kemiskinan sedangkan pengaruh belanja pemerimtah secara tidak langsung melalui pertumbuhan ekonomi berpengaruh positif terhada kemiskinan. Inflasi secara langsung berpengaruh negatif terhadap kemiskinan sedangkan pengaruh inflasi secara tidak langsung melalui pertumbuhan ekonomi berpengaruh positif terhadap kemiskinan Investasi secara langsung maupun tidak langsung melalui pertumbuhan ekonomi tidak berpengaruh terhadap kemiskinan Pertumbuhan ekonomi secara langsung tidak berpengaruh terhadap kemiskinan, sedangkan pengaruh pertumbuhan ekonomi secara tidak langsung berpengaruh negatif terhadap kemiskinan melalui pengangguran dan pengaruh pertumbuhan ekonomi secara tidak langsung tidak berpengaruh terhadap kemiskinan melalui pendapatan perkapita. Pemerintah selaku pembuat kebijakan harus lebih konsisten dan fokus dalam merealisasikan anggaran yang berorientasi pada peningkatan pelayanan publik sehingga tingkat kesejahteraan masyarakat dapat meningkat yang pada akhirnya kemiskinan dapat menurun dan melakukan upaya untuk mendorong peningkatan investasi pemerintah proporsional dan lebih memihak kepada kepentingan publik sehingga mampu memberikan efek positif terhadiap pertumbuhan ekonomi dan pengentasan kemiskinan nasional.

\section{DAFTAR PUSTAKA}

Aritonang Triana Mauliasih. 2012. Kemiskinan, Investasi dan Pertumbuhan Ekonomi di $\begin{array}{llll}\text { Indonesia Tahun } & 1981 \text {. } & 2011 . & \text { Diakses dari } \\ \text { pustaka unpad.ac.id/.../pustaka unpad kemiskinomidi }\end{array}$ tanggal 3 Desember 2014, Pukul 15.20.

Dumairy MA. 1996. Perekonomian Indonesia. Penerbit Erlangga. Jakarta

Paseki Meilen Greri dkk. 2014. Pengaruh Dana Alokasi Umum dan Belanja Langsung terhadap Pertumbuhan Ekonomi dan Dampaknya terhadap Kemiskinan di Kota Manado Tahun 2004- 2012. Diakses dari http /lejoumal unsrat. Pukul 17.00. Pada tanggal $24 \mathrm{Mei} 2015$.

Prastyo Adit Agus. 2010. Analisis Faktor- Faktor yang Mempengaruhi Tingkat
Kemiskinan. Semarang Kemiskinan. Semarang : FE UNDIP. Diakses dari 
Sari Andi Arini Putri. 2013. Analisis Dampak Pengeluaran Pemerintah di Bidang Pendidikan, Kesehatan, dan Pengeluaran Subsidi terhadap Kemiskinan di Indonesia. Diakses dari https://pengkajian.dpr.go.id. Pada tanggal 1 Januari 2015, Pukul 21.00.

Sukirno Sadono. 2000. Makro Ekonomi Modem Perkembangan Pemikiran Klasik Hingga Keynesian Baru. Penerbit PT Raja Grafindo Persada : Jakarta.

Todaro Michael P. 2000. Pembangunan Ekonomi di Dunia Ketiga (Terjemahan). Penerbit Erlangga : Jakarta.

Todaro Michael P. 2006. Pembangunan Ekonomi di Dunia Ketiga. Penerbit Erlangga : Jakarta.

Yudha Okta Ryan Pranata. 2013. Pengaruh Pertumbuhan Ekonomi, Upah Minimum, Tingkat Penagguran Terbuka Terhadap Kemiskinan di Indonesia Tahun 20092011. FE : Universitas Negeri Semarang. Diakses dari lib.unnes.ac.id/17313/1/7111409012.pdf. Pada tanggal 13 Desember 2014, Pukul 11.10. 